by Matilda Thomas ${ }^{1}$, Jonathan D.A. Clarke ${ }^{1}$, Victor A. Gostin ${ }^{2}$, George E. Williams ${ }^{2}$ and Malcolm R. Walter ${ }^{3}$

\title{
The Flinders Ranges and surrounds, South Australia: a window on astrobiology and planetary geology
}

${ }^{1}$ Geoscience Australia, GPO Box 378, Canberra, ACT 2601, Australia. E-mail: matilda.thomas@ga.gov.au; jon.clarke@ga.gov.au ${ }^{2}$ Geology and Geophysics, University of Adelaide, SA 5005, Australia.E-mail: victor.gostin@adelaide.edu.au; george.williams@adelaide.edu.au ${ }^{3}$ Australian Centre for Astrobiology, University of New South Wales, NSW 2052, Australia. E-mail: malcolm.walter@unsw.edu.au

The Flinders Ranges and its surroundings in South Australia comprise an impressive rugged terrain that rises abruptly from piedmont plains to the east and west and merges into the plains of the Cenozoic Lake Eyre Basin to the north. Folded and faulted NeoproterozoicCambrian clastic and carbonate sedimentary rocks of the Adelaide Geosyncline (Adelaide Rift Complex) form the predominant geology of the ranges and record varied depositional environments and metamorphic overprints and have had a complex landscape history, resulting in a diverse regolith. This ancient, arid terrain represents some of the best analogue landscapes and settings in Australia to observe features and processes fundamental to the evolution of the Earth. The strata of the Flinders Ranges record the evolution of terrestrial surface environments and the biosphere through the Cryogenian, Ediacaran and Cambrian periods, including evidence for Neoproterozoic glaciations, orbital and rotational dynamics and asteroid impact. The diverse assemblages of stromatolites, ancient and modern hydrothermal systems, and alteration assemblages provide field laboratories for astrobiological and hyperspectral research and training. For these reasons the northern Flinders Ranges near Arkaroola have been selected as a site for multi-disciplinary Mars analogue research and space education.

\section{Introduction}

Analogue research involves an integrated set of disciplines investigating terrestrial features and processes which can offer insights into understanding landscapes and processes observed on other planets. Analogue features also serve as training grounds for planetary scientists and astrobiologists and as field test sites for equipment and instruments used in planetary exploration. Analogues should be distinguished from simulation, for example the dunes of the Strzelecki Desert are potentially good morphological and process analogues for martian dunes (Bishop, 1999) but they are not good simulations of martian dunes because of the different gravity, composition and atmospheric conditions between the Strzelecki Desert and Mars.

Australian geology and landscapes provide numerous opportunities for analogue research, in particular, Mars analogue research (West et al., 2009) because of the preservation of its long geological history, including extensive hydrothermal activity and a predominantly arid climate. The diversity of processes and landforms found in regions such as the Flinders Ranges and the surrounding area in central South Australia, in particular the features found within c. $100 \mathrm{~km}$ of Arkaroola, offer powerful insights into extraterrestrial and especially martian stratigraphy and geomorphology, along with astrobiology sites and examples. The Arkaroola region has been used for a range of Mars-related research and education activities including remote sensing (Thomas and Walter, 2002; Brown et al., 2004), landscape evolution (Waclawik and Gostin, 2006), engineering research related to planetary exploration (Waldie and Cutler, 2006) and education and outreach in all these disciplines (Laing et al., 2004; West et al., 2009).

This paper provides a brief description of some features in the Flinders Ranges and surrounds of interest to those studying astronomical influences on terrestrial geology, Mars analogues, and astrobiology that will be visited during a field trip associated with the 34th International Geological Congress (34 IGC). These are:

- Proterozoic and Phanerozoic rocks of the northern Flinders Ranges

- Regolith and landscapes of the northern Flinders Ranges

- Astrobiological features in the northern Flinders Ranges and surrounds

- Neoproterozoic stromatolites at Arkaroola

- A possible Neoproterozoic deep hot biosphere

- Fossil hydrothermal systems of the Mount Painter Inlier, Arkaroola

- Paralana Hot Springs, Arkaroola

- Cryogenian glacials, Arkaroola

- Late Cryogenian tidal rhythmites and Earth's paleorotation, Pichi Richi Pass

- Ediacaran Acraman impact ejecta horizon, Bunyeroo Formation, Central Flinders Ranges 


\section{Geology of the northern Flinders Ranges}

The geology of the Neoproterozoic Adelaide Geosyncline (also termed the Adelaide Rift Complex) is reviewed by Preiss (1987, 1993, 2000), with Coats and Blissett (1971) focusing on the Mount Painter area and its surrounds. The Paleozoic, Mesozoic and Cenozoic successions of the region are reviewed by Drexel and Preiss (1995). These works remain unsurpassed in providing a framework to understanding the geology of the region.

Arkaroola is located in the northern Flinders Ranges (Figure 1), where rocks of the Mount Painter Inlier form a basement nucleus over which a younger Neoproterozoic succession was deposited. The Mount Painter Inlier comprises Mesoproterozoic metasediments and metavolcanics (including the Radium Creek Metamorphics) intruded by granites, pegmatites and minor amphibolite dykes. The highly radiogenic nature of the Mesoproterozoic granites has resulted in a long-lasting history of hydrothermal activity that has continued to the present.

The Neoproterozoic succession includes numerous horizons of stromatolitic carbonates, evidence for two Cryogenian glaciations, and an Ediacaran impact ejecta horizon derived from the Acraman impact structure in the adjacent Gawler Ranges. The main phase of

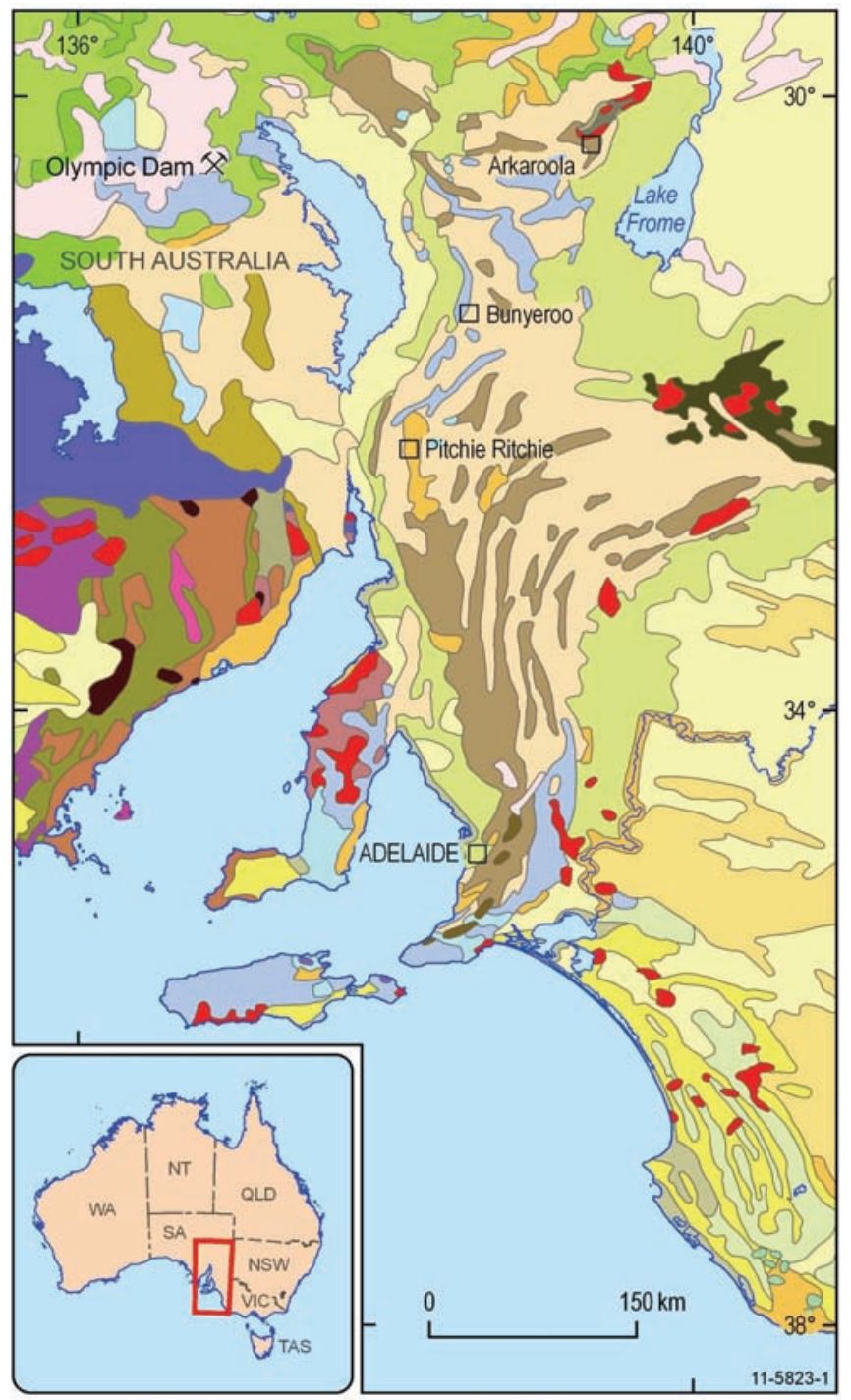

Figure 1 Regional geological context of the study area. deformation was the Ordovician Delamerian Orogeny at 514-490 Ma (Drexel and Preiss, 1995; Foden et al., 2006). Ordovician granites and pegmatites form a younger granite suite which intrudes the Proterozoic basement (Hore et al., 2005).

Mesozoic and early Cenozoic sediments unconformably overlie the Proterozoic and Paleozoic rocks. This cover has been almost completely removed by later Cenozoic reactivation and uplift of the folded strata to form the Flinders Ranges. The youngest Cenozoic sediments form piedmont alluvial aprons derived from the ranges.

\section{Regolith and landscapes of the northern Flinders Ranges and surrounds}

Regolith and associated paleolandscapes within the Mesozoic Eromanga Basin include a paleodrainage deposition (fluvial and minor glacial) in a landscape of moderate topographic relief and bedrock exposure (Davey and Hill, 2007; Hill and Hore, 2009). Cretaceous marine transgressions across low-lying parts of the landscape deposited chemically reduced clays and silts. The Mesozoic sediments have since been partially oxidised and tectonically disrupted, particularly during the Neogene (Davey and Hill, 2007). Early Cenozoic regolith and landscape evolution is associated with the development of the Lake Eyre Basin region and Paleogene fluvial deposits. Ephemeral fluvial, lacustrine, colluvial and aeolian deposition, as well as tectonism and pedogenesis, have been spatially and temporally variable in the more recent geological evolution (Hill, 2008).

The youngest Cenozoic landscapes of the plains to the east and north of the Arkaroola region record a complex evolution under changing climatic conditions (Twidale and Bourne, 1996; Twidale and Wopfner, 1996; Hill, 2008). Major alluvial fan systems occur along the range front and drain into the adjacent salt lakes (Frome, Grace, Blanche and Callabonna) or into the dune fields on the margin of the Strzelecki Desert. The fans are variably duricrusted and dissected and record a Quaternary history of fan deposition and incision related to both climate change and tectonics. Examples of these Cenozoic deposits flank the Flinders Ranges at the Paralana Hot Springs (see below). The various surfaces, duricrusts and sediments provide an analogue for the complex landforms to be expected on Mars. Some of these deposits, such as the mobile barchanoid sand dunes at Gurra Gurra Waterhole, have previously been studied as Mars analogues (Bishop, 1999).

\section{Astrobiology in the Flinders Ranges}

Astrobiology is the study of the origin, evolution, distribution, and future of life in the universe. This multidisciplinary field encompasses the search for habitable environments... the search for evidence of prebiotic chemistry and life on Mars and other bodies in our Solar System, laboratory and field research into the origins and early evolution of life on Earth, and studies of the potential for life to adapt to challenges on Earth and in space. From: "About Astrobiology”. (NASA Astrobiology Institute, 2008).

\section{Neoproterozoic stromatolites at Arkaroola}

There are numerous Neoproterozoic stromatolitic carbonates and associated chert formations within the Adelaide Geosyncline, which 
may contain microfossils. These include the oldest carbonates of the Callanna Group and the Skillogalee Dolomite of the Burra Group, (both pre-Cryogenian), the Cryogenian interglacial carbonates of the Balcanoona, Etina and Trenzona formations, the Ediacaran Wonoka Formation, and numerous horizons in the Cambrian (Coats, 1972; Preiss, 1987, 1993, and references therein). They attest to a flourishing photosynthetic bacterial microbiota that was widespread in marine (and probably also lacustrine) environments ranging from peritidal to the base of the photic zone (c.100-150 m depth) during favourable conditions throughout the region. In the Arkaroola area, the best preserved stromatolites are found in the Balcanoona Formation as large reefs up to $1.1 \mathrm{~km}$ thick, with associated enigmatic structures that may be sponges (Giddings et al., 2009). Fore-reef, reef-margin and back-reef facies are all well represented.

The astrobiological significance of stromatolites lies in their ubiquity, as they are the oldest known macroscopic evidence of life on Earth and are found in diverse environments including saline and freshwater lakes, intertidal flats, springs, hydrothermal vents, and both shallow and deep marine. While not all stromatolite-like structures are biogenic, not all biogenic stromatolites preserve microfossils or biomarkers (Brasier et al., 2002; Schopf, 2006), and both microfossils and biomarkers can be found in non-stromatolitic lithologies (Marshall, 2007). Recognition of stromatolite-like features on Mars would be a major discovery and would provide a focus for subsequent investigations. Therefore various researchers have suggested that recognition for stromatolitic morphologies be included in the search for life on Mars (e.g., Walter and Des Marais, 1993; McKay and Stoker, 1989), as well as drawing parallels between terrestrial stromatolites and what might be found on Mars (e.g., Allwood et al., 2007; Van Kranendonk, 2006).

\section{A possible Neoproterozoic deep hot biosphere}

The Arkaroola region is also notable for the serendipitous discovery of possible evidence for a deep hot biosphere that inhabited Neoproterozoic sedimentary successions during peak burial and metamorphism. While examples of such organisms are known from deep wells today (Fyfe, 1996) and have been postulated to have lived as long as 3.8 billion years ago (Pinti et al., 2001), fossil examples are poorly known. Structural investigations by Bons and Montenari (2005) examined fibrous anataxial calcite veins in the Tindelpina Shale Member of the Tapley Hill Formation. These formed at c. $585 \mathrm{Ma}$ at an estimated 3-6 km depth. Scanning electron microscope observations revealed about 1-micron-sized structures within the veins. Further studies showed that these structures were composed of calcite but contained higher sulfur than the surrounding material. Fluid inclusions in the calcite indicate a temperature of formation of c. $60-80^{\circ} \mathrm{C}$, and not exceeding $100^{\circ} \mathrm{C}$. While a nonbiogenic origin of the objects is possible, it was considered unlikely (Bons et al., 2007). The weight of evidence from morphology, chemistry and size distribution indicates that the objects are fossilised microbes that lived in the veins at the time and depth of vein formation. Further work is needed on the structures to test their biogenicity. If these features are indeed biogenic they are a potential analogue for a possible martian habitat (Hoffmann and Farmer, 2000).

\section{Mount Painter/Mount Gee}

The Mount Painter area contains a complex collection of breccias, which are characterised by large dyke-like bodies of siliceous hematitic breccia and are interpreted to represent hydrothermal systems (Hore and Hill, 2009). This hydrothermal activity is most evident in the area centred on Mount Painter and Mount Gee (Sprigg, 1945; Drexel and Major, 1987) with lesser expressions to the east at Livelys Find Au prospect (Collier, 2000) and to the northeast at the Hodgkinson U prospect (Smith, 1992). Many of these breccias contain U and minor sulfide mineralisation. The breccias occur as irregular bodies within the basement complex, adjacent to a zone of extensive faulting, which also contains Ordovician granites and pegmatites (Lambert et al., 1982). The Mount Gee system includes a range of features including crustiform and colloform textures, bladed and replacement carbonate, fluorite, zeolites and siliceous fluids resulting in cavity-fill crystallisation and jasperoidal formations as seen in Figure 2 (Hore, 2008). The jasperoidal unit at Mount Gee could have been deposited as a gel (e.g., Eugster and Jones, 1967), and many textures in the Mount Painter and Mount Gee silica deposits are similar to the botryoidal silica surfaces observed at the Sleeper Au deposit in Nevada (Saunders, 1994) and the recrystallised silica gels from Yellowstone National Park (Fournier et al., 1991). While the preservation of microfossils would appear likely in the Mount Painter hydrothermal deposits, preliminary attempts to find them have been unsuccessful (Carlton, 2002).

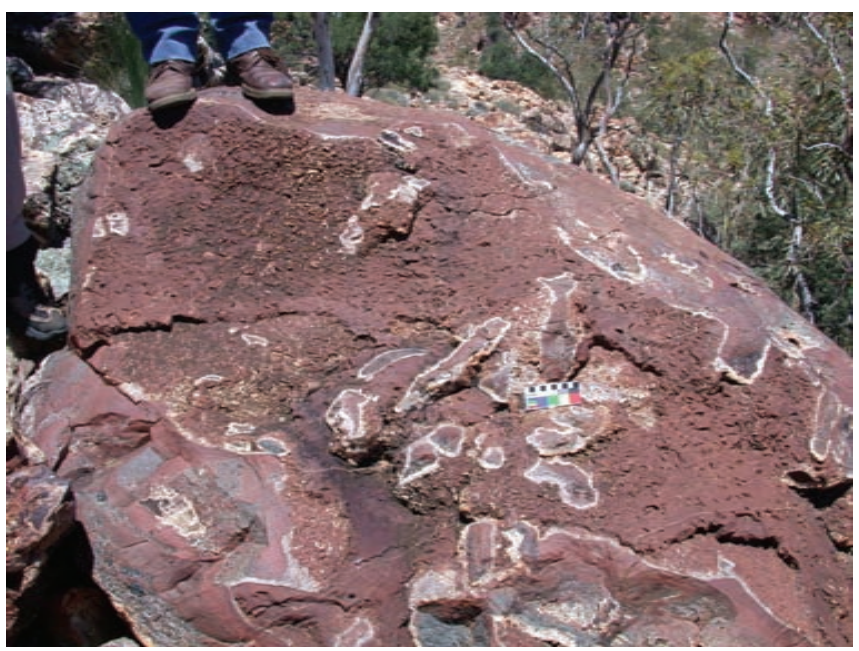

Figure 2 Mount Gee epithermal quartz.

Ancient hot-spring deposits and associated hydrothermal alteration exemplify key environments in the exploration and study of earliest life on Earth (e.g., Bock and Goode, 1996). These systems could have similar significance in the search for extraterrestrial life, and particularly on our nearest neighbour, Mars, where hydrothermal activity is likely to have occurred in the past and may even continue somewhere underground today (e.g., Walter and Des Marais, 1993; Catling and Moore, 2003). Martian hematite-precipitating spring deposits are high-value targets for martian astrobiology missions, in particular sample return missions (Catling and Moore, 2003; Allen et al., 2001, 2004). The hematite-rich shallow hydrothermal systems of the Mount Painter Inlier are therefore of considerable astrobiological interest as Mars analogues (Thomas and Walter, 2002, 2004; Brugger et al., 2011) because of the high preservation potential for both microfossils and organic matter in the silica-hematite precipitates. The high radiation environment of these systems, of which Paralana Hot Springs (see below) is the current example, provides another 
similarity to the surface of Mars, while the association of hydrothermal activity with an icy surface environment in the Mount Painter hydrothermal system appears unique for a fossil terrestrial hydrothermal system (Brugger et al., 2011) and is a further parallel for what might be found on the surface of Mars.

Alteration (including hydrothermal) can be detected in hyperspectral data in regions like the Mount Painter Inlier (Thomas and Walter, 2002; Brown and Thomas, 2004; Brown et al., 2004). Studies indicate that careful band selection and testing in terrestrial field analogues are required if spacecraft systems are to detect hydrothermal alteration on Mars and differentiate it from more regional alteration signatures.

\section{Radioactive hot springs of the Paralana Fault Zone}

The Paralana Fault Zone, consisting of northeast-trending faults, runs along the eastern margin of the Mount Painter Inlier, northeast of Arkaroola (Figure 1). The fault zone is associated with an area of anomalously high heat flow attributed to high concentrations of radioactive elements in Mesoproterozoic granites of the adjacent Mount Painter Inlier and is generally believed to be the main conduit for hydrothermal fluid dispersal in the area (Coats and Blissett, 1971; Thomas and Walter, 2002; Brugger et al., 2005). Hydrothermal activity during the Paleozoic has produced large volumes of uraniferous breccias, siliceous deposits (possibly sinters), and $\mathrm{Cu}-\mathrm{Fe}$ and $\mathrm{Fe}-\mathrm{U}$ deposits. Leaching of these deposits may have contributed to the secondary $U$ deposits in Cenozoic sandstones east of the Inlier (Brugger et al., 2005). The Paralana Hot Springs occur to the north east of Mount Painter on the Paralana Fault Zone (Figures 1 and 3). The springs are evidence of continuing hydrothermal activity along the fault zone. The source of this fluid and of past hydrothermal fluids is difficult to ascertain, although it is most likely to be predominantly meteoric in origin (Foster et al., 1994) representing the surface expression of a cyclic, low-temperature, non-volcanic hydrothermal system (Brugger et al., 2005).

Water from the Paralana Hot Springs is neutral $(\mathrm{pH} 7-8)$ and the springs discharge $16 \mathrm{~L} / \mathrm{s}$ at a temperature of $57^{\circ} \mathrm{C}$. The $5 \mathrm{ppm} \mathrm{F}$, 33 ppb Mo, 11 ppb W, 16 ppb Cs and 200 ppb Rb concentrations in the spring water are comparatively high. $\delta^{13} \mathrm{C}$ values of $\mathrm{CO}_{2}(\mathrm{~g})$

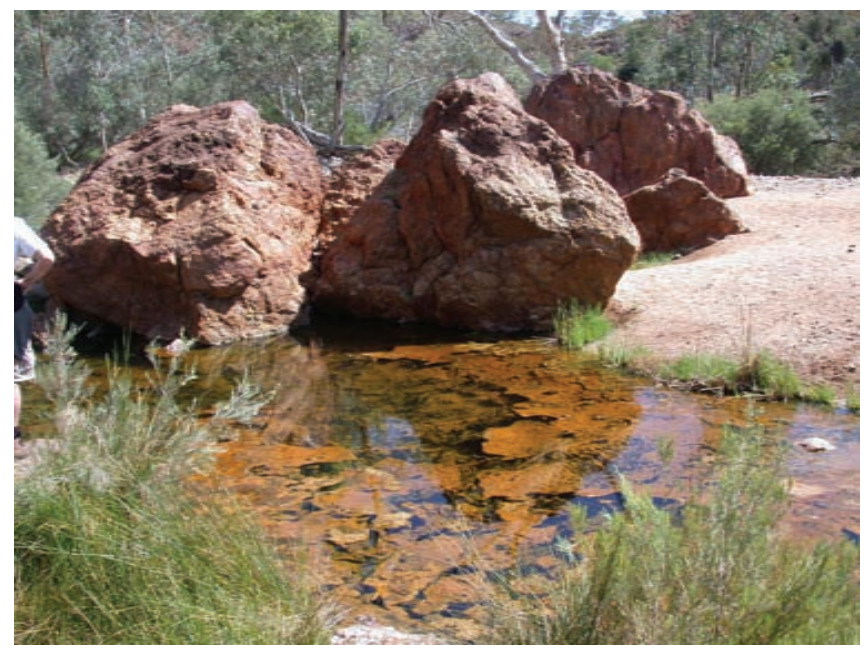

Figure 3 Paralana Hot Springs source pool and microbial communities. emanating from the springs and dissolved $\mathrm{HCO}_{3}^{-}$suggest that the carbon source is organic matter, e.g., soil or plants. Radon concentrations at the springs are very high (radiation of 10,952 Bq/ $\mathrm{m}^{3}$ ), suggesting a localised radiogenic source at shallow depth (Brugger et al., 2005). These radiogenic springs are not associated with any active volcanism, and therefore provide an opportunity to study the effects of amagmatic heat sources, which could drive a hydrothermal system for an extended timeframe, perhaps a billion years or more (Brugger et al., 2011).

Studies of hot springs have shown they support a high diversity of bacteria and Archaea. The hot spring environs at Paralana have been studied as an analogue for early life, and microbial adaptation to extreme temperatures and radioactivity levels (e.g., Anitori et al., 2002). The composition of microbial ecosystems around subaerial hot springs and submarine vents is significant to the understanding of early life on Earth and tracing evolutionary phylogenic trees, and interpreting presumed biomarkers (microfossils, lipids, isotopes etc.) found in these ancient systems (Walter and Des Marais, 1993). Analysis of bacterial communities by Anitori et al. (2002) indicated that a diverse community of bacteria is supported by the waters at the Paralana Hot Springs. The presence of Ra gas, which bubbles up intermittently in the thermal source pool, makes the Paralana Hot Springs highly suited as an analogue for ionising radiation environments, which may have been common on the early Earth and Mars.

\section{Cryogenian glacials}

Sedimentological and paleomagnetic studies of Cryogenian glacial deposits in South Australia have been a stimulus for worldwide multidisciplinary research on the nature and extent of Cryogenian glaciations. Two major glaciations are recorded in the succession, the earlier Sturt glaciation (Preiss et al., 2011) and the later Elatina glaciation (Lemon and Gostin, 1990; Williams et al., 2008, 2011), often incorrectly referred to as the Marinoan glaciation.

The late Cryogenian (c. $630 \mathrm{Ma}$ ) Elatina glaciation in South Australia is represented by a spectrum of facies (Figure 4). The periglacial-aeolian Whyalla Sandstone on the Stuart Shelf passes eastwards into glaciofluvial, deltaic, littoral and inner marine-shelf deposits of the Elatina Formation and outer marine-shelf diamictite and mudstone-siltstone with dropstones in the Adelaide Geosyncline. Important features of the Elatina glaciation include the widespread and persistent rainout of fine-grained sediment and ice-rafted debris, grounded ice on diapiric islands within the basin and on cratonic regions in the east (but absent on the Gawler Craton in the west). Other key features include permafrost near sea level with a strongly seasonal periglacial climate, glaciofluvial deposition, several glacial advances and retreats, wave-generated ripple marks, and the annual (seasonal) oscillation of sea level (Preiss, 1987; Lemon and Gostin, 1990; Williams et al., 2008, 2011). The plaque for the Global Stratotype Section and Point (GSSP) for the recently established Ediacaran System and Period (Knoll et al., 2006) is placed between the Elatina Formation and the overlying Nuccaleena Formation in Enorama Creek in the central Flinders Ranges.

The late Cryogenian glacials in South Australia were deposited at low paleolatitudes (Figure 4, inset), as shown by high-quality paleomagnetic data for red beds from the Elatina Formation that demonstrate the early acquisition of magnetic remanence and deposition within $10^{\circ}$ of the paleoequator (Schmidt et al., 1991, 2009; 


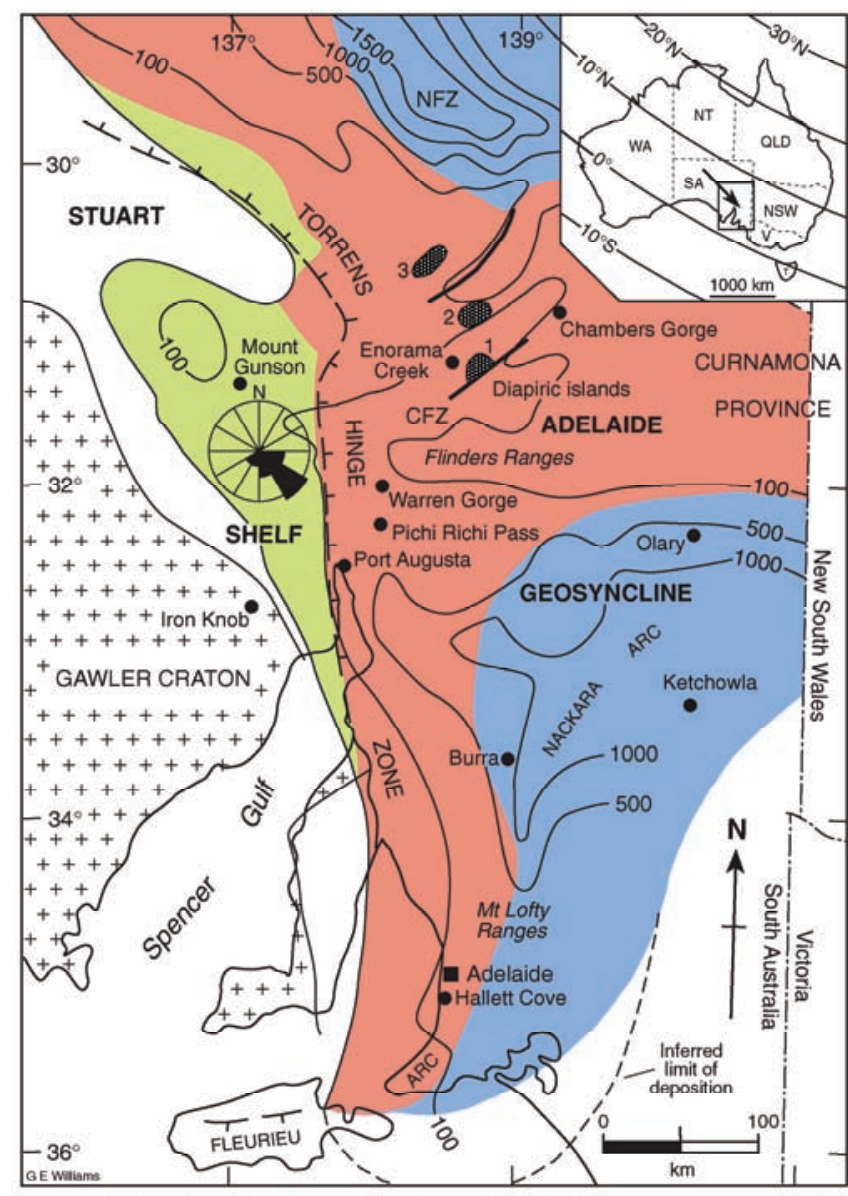

Periglacial: aeolian
sands, permafrost

Outer marine-shelf
diamictite, siltstone
Figure 4 Facies of the late Cryogenian Elatina glaciation. Isopachs in metres. $\mathrm{CFZ}=$ Central Flinders Zone, $\mathrm{NRZ}=$ North Flinders Zone. 1, 2, 3 = diapiric islands. Paleowind rose diagram for the Whyalla Sandstone. Inset shows paleolatitudes and paleowind direction (arrow). After Williams et al. (2008).

Schmidt and Williams, 1995; Sohl et al., 1999). However, the indicated paleogeography, with extensive and long-lived open seas, unglaciated continental regions and an active hydrological cycle, conflicts with the "snowball Earth" hypothesis of Hoffman and Schrag (2002).

The older, Sturt glaciation is equally well represented by diverse facies throughout the Flinders Ranges (Preiss, 1987, 1993; Young and Gostin, 1989). At Stubbs Waterhole, $5 \mathrm{~km}$ from Arkaroola, spectacular thick-bedded sandy boulder and pebble conglomerates with diverse lithologies were deposited from vigorous glacial meltwater streams. It is believed that during the middle Cryogenian an elevated large ice cap covered the whole area between the Mount Painter Inlier and Broken Hill (250 km to the southeast). Major thickness variations of the c. $500 \mathrm{~m}$ thick Bolla Bollana Formation reflect rapid subsidence in rifted basins.

\section{Tidal rhythmites and Earth's paleorotation, Pichi Richi Pass}

The Elatina Formation near the margins of the Adelaide Geosyncline includes tidal rhythmites of siltstone and fine-grained sandstone deposited on a series of ebb-tidal deltas and estuarine tidal flats that formed during a high stand of sea level during temporary glacial retreat (Williams, 1991, 2000; Williams et al., 2008). The finegrained sediment load of ebb tidal currents is related directly to tidal range (or maximum tidal height), and deposition offshore from ebbtidal jets and plumes forms neap-spring cycles comprising semidiurnal and diurnal (lunar day) graded laminae mostly of fine sand and silt, with mud bands deposited during slack water at neaps (Figure 5). The rhythmite unit is $18 \mathrm{~m}$ thick at Warren Gorge (Williams, 1996) and somewhat thinner at a more distal setting in Pichi Richi Pass (Figure 4) where exposure is limited.

Detailed study of cores from three vertical holes drilled through the rhythmite unit in Pichi Richi Pass have provided an internallyconsistent paleotidal data-set comprising numerous tidal cycles ranging from semidiurnal to the lunar nodal cycle $(9.4 \mathrm{~m} \mathrm{log}$ of 1580 successive fortnightly neap-spring cycles recording 60 years of continuous deposition; Williams, 1991). The neap-spring cycles contain 8-16 diurnal laminae, with many cycles abbreviated at neaps (Figure 5b); semidiurnal increments occur locally, and are conspicuous in thicker neap-spring cycles from tidal rhythmites in the correlative Reynella Siltstone Member near Hallett Cove, $300 \mathrm{~km}$ to the south (Figures 5a and 6). Paleotidal cycles resulting from variation in the thickness of successive neap-spring cycles compare closely with modern tidal patterns for Townsville, Queensland (Figure 7): features common to both data sets include first-order peaks marking the solar year and the annual oscillation of sea level, second-order peaks marking the semiannual tidal cycle, and a sawtooth pattern reflecting alternate high and low spring tides due to the eccentric lunar orbit. The duration of Elatina rhythmite deposition matches the c. 70 year

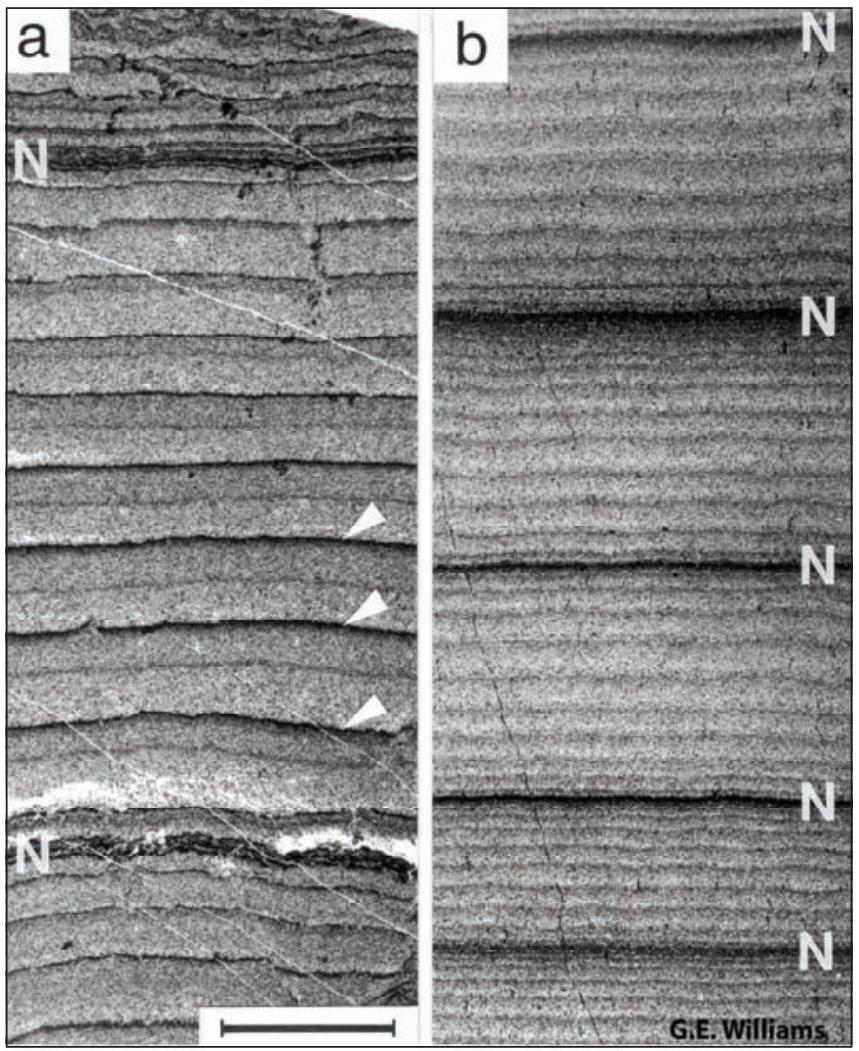

Figure 5 Neap-spring cycles of late Cryogenian tidal rhythmites. Scale bar $1 \mathrm{~cm}, N$ = neap-tidal muddy bands. (a) Reynella Siltstone Member; diurnal laminae have mudstone tops (arrows) and comprise semidiurnal increments. (b) Elatina Formation, Pichi Richi Pass. From Williams (2004). 


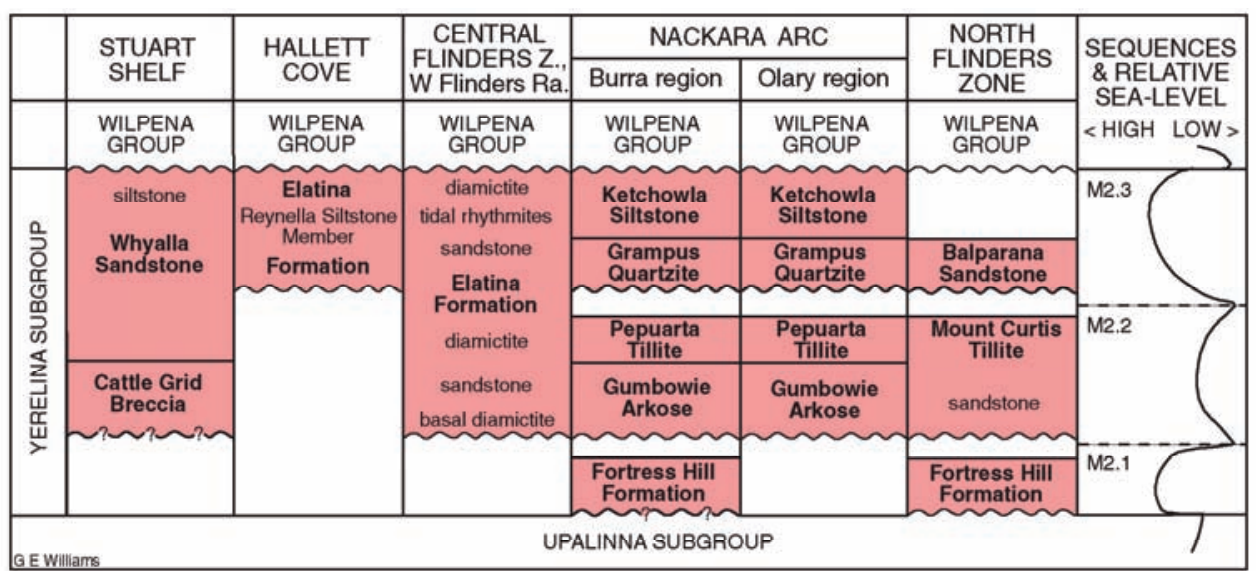

Figure 6 Stratigraphy of the late Cryogenian Yerelina Subgroup, which encompasses all the units of the Elatina glaciation in South Australia. After Preiss et al. (1998) and Williams et al. (2008), with Marinoan sequence sets M2.1-M2.3 and relative sea-level curves from Preiss (2000).

$96.5 \pm 0.5 \%$ of the present distance (Williams, 1991, 2000). The rhythmites also record the non-tidal, annual oscillation of sea level (Figure 7), which is a response mostly to seasonal changes in water temperature as well as variation in winds and atmospheric pressure, indicating extensive open seas during late Cryogenian glaciation (Williams et al., 2008, 2011)

\section{Acraman impact ejecta horizon in Bunyeroo}

\section{Gorge}

The Acraman impact ejecta horizon (AIEH) in the mid-Ediacaran (c.580 Ma)

morphologic cycle for a modern ebb-tidal delta (Ping, 1989). Comparable tidal rhythmites occur in modern glaciomarine settings (Smith et al., 1990; Cowan et al., 1999).

Information on the Earth's paleorotation and the Moon's orbit in late Cryogenian times revealed by time-series analysis of the Elatina core log, supplemented by data for the Reynella Siltstone Member, includes $13.1 \pm 0.1$ lunar months/year, $400 \pm 7$ solar days/year, $21.9 \pm 0.4$ hours/solar day, and a mean Earth-Moon distance of
Bunyeroo Formation (Gostin et al., 1986, 1989) was the first Precambrian impact ejecta deposit to be linked to a specific astrobleme, the Acraman impact structure on the Gawler Craton, several hundred kilometres to the west (Williams, 1986). The AIEH consists of a solitary thin layer of red dacitic fragments and sand, enveloped by a reduction halo of grey-green shale, and is well exposed within marineshelf maroon shale $80 \mathrm{~m}$ above the base of the $400 \mathrm{~m}$ thick formation (Figure 8). The volcanic fragments show features of shock
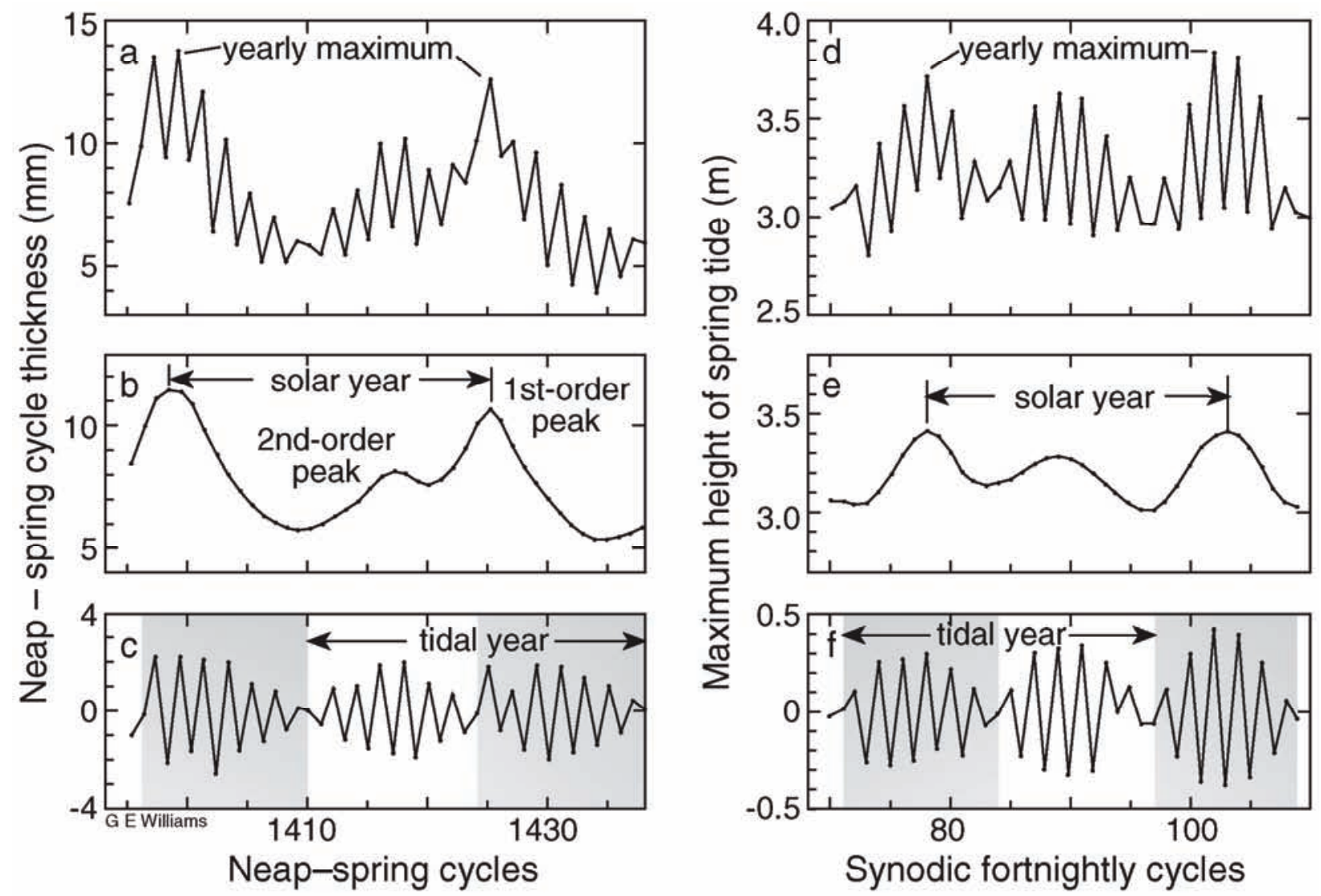

Figure 7 Tidal patterns for $(a-c)$ the late Cryogenian Elatina rhythmites and (d-f) Townsville, Queensland, for 19 October 1968 to 3 June 1970. ( $a, d)$ Unsmoothed curves. (b, e) Smoothed curves. (c, $f$ ) Residuals (a minus $b ; d$ minus e), showing $180^{\circ}$ phase changes in the sawtooth patterns. From Williams (1991, 2000). 


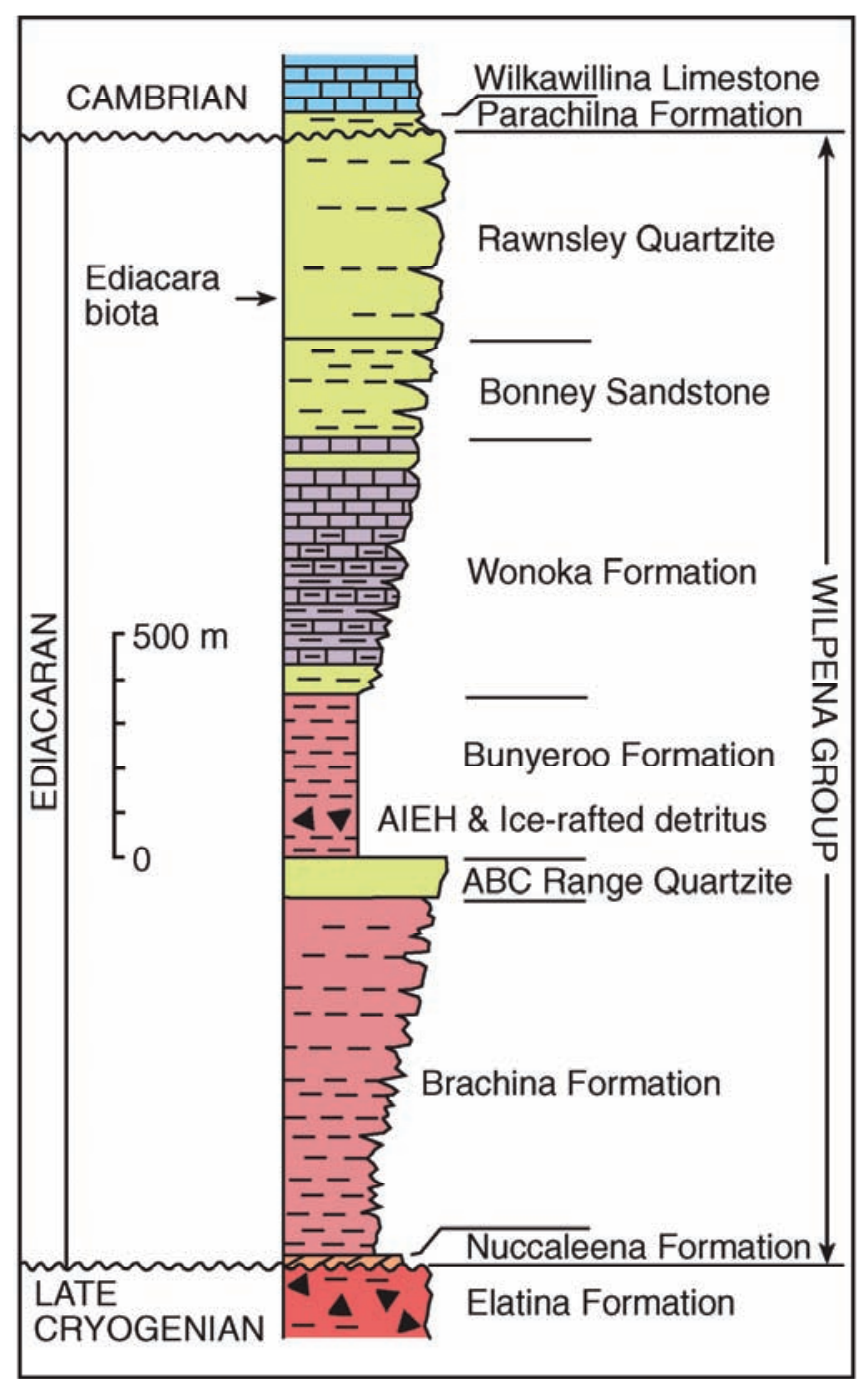

Figure 8 Stratigraphic column for Ediacaran strata in the central Adelaide Geosyncline. AIEH = Acraman impact ejecta horizon. The famous metazoan fossil assemblage (Ediacara biota) occurs near the base of the Rawnsley Quartzite (Preiss, 1987, 2000). After Williams and Gostin (2005).

metamorphism and the horizon is anomalous in cosmogenic siderophile elements, including Ir (Gostin et al., 1989). U-Pb zircon dating, paleomagnetic data and the regional distribution of the ejecta confirm derivation of the volcanic fragments from the Acraman impact structure in the 1592 Ma Yardea Dacite on the Gawler Craton (Compston et al., 1987; Schmidt and Williams, 1996; Williams and Wallace, 2003; Williams and Gostin 2005). Typical sections of the ejecta are shown in Figure 9 and ejecta regional distribution in Figure 10.

The magnitude, age and potential environmental effects of the Acraman impact and the nature of the AIEH were reviewed by Williams and Wallace (2003) and Williams and Gostin (2005). The Acraman impact structure is complex, with a transient cavity $40 \mathrm{~km}$ in diameter and a final structural rim (90 km diameter) that is eroded $\geq 2.5 \mathrm{~km}$ below the original crater floor. The AIEH in the Adelaide Geosyncline occurs at radial unfolded distances of up to $400 \mathrm{~km}$ from the centre of the Acraman structure. The impact occurred at a low (c. $12.5^{\circ}$ ) paleolatitude and probably perturbed the atmosphere in both the northern and southern hemispheres. The dimensions of Acraman
Style 1 facies

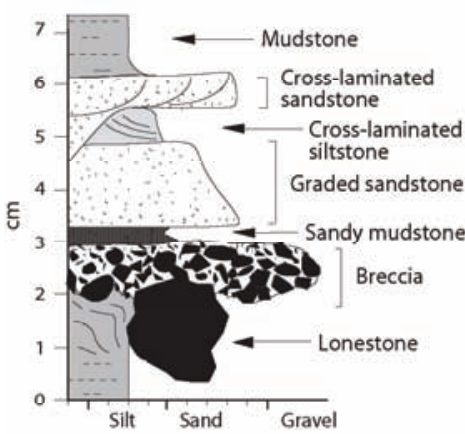

Style 2 facies

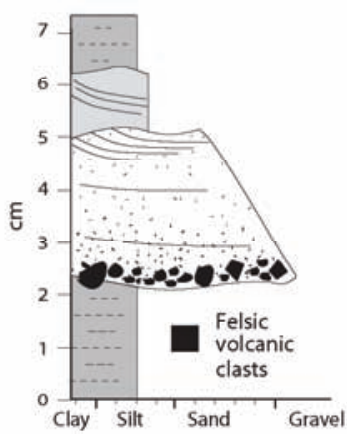

Figure 9 Principal styles for the ejecta horizon in the Bunyeroo Formation. Style 1 (Bunyeroo Gorge-Brachina Gorge area) represents primary fallout deposited from suspension. Style 2 (western Adelaide Geosyncline) represents ejecta reworked by impact-induced tsunamis. After Wallace et al. (1996).

structure indicate that the impact would have caused earthquakes, tsunamis, atmospheric ozone loss, and the global dispersal of a dust cloud that lowered light levels below those required for photosynthesis.

The presence of ice-rafted dropstones, granule clusters, frozen aggregates and till pellets in mudstones of the lower Bunyeroo Formation in the central Adelaide Geosyncline (Figures 8 and 10) and in the correlative Dey Dey Mudstone (Officer Basin) implies a cold climate and nearby areas of freezing and glaciation both before and after the Acraman impact (Gostin et al., 2010). Following

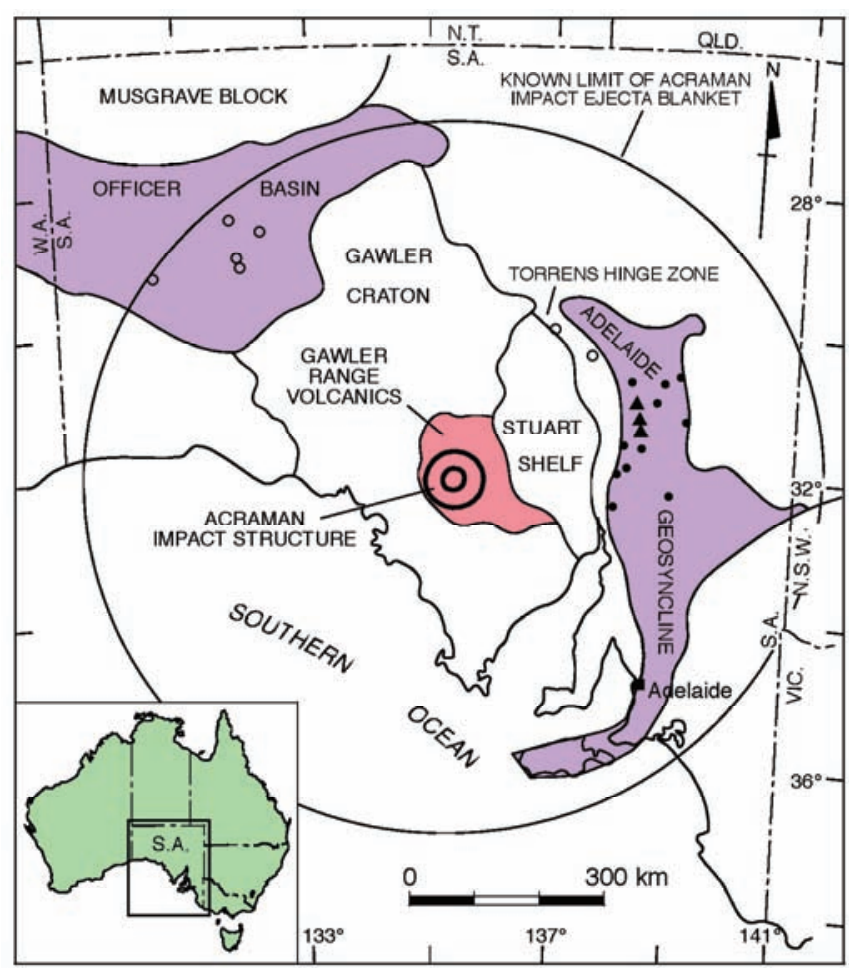

Figure 10 Location of the Acraman structure and the Acraman impact ejecta horizon in mid-Ediacaran strata. Solid circles indicate ejecta seen in outcrop, and open circles ejecta recorded in drill core. Triangles indicate ice-rafted detritus and ejecta seen in close stratigraphic proximity. From Gostin et al. (2010). 
glaciation and impact, the overlying Ediacaran succession shows a negative carbon isotopic excursion, rapid diversification of acanthomorph acritarchs, and biomarker hydrocarbon anomalies, climaxing with the advent of metazoans. Release from the combined environmental stresses of glaciation and impact may have expedited biotic evolution in the later Ediacaran (Grey et al., 2003; McKirdy et al., 2006; Gostin et al., 2010).

\section{Conclusions}

This paper highlights a selection of features in the central and northern Flinders Ranges that illustrate important events and processes in the physical evolution of the Earth as a planet, including the widespread Neoproterozoic glaciations, the rotational and orbital evolution of the Earth-Moon system, and asteroid impact. Stromatolitic successions provide examples of their sedimentary role and morphological evolution during the Cryogenian through to the Cambrian. Also highlighted are some of the features that provide analogues for possible sites on Mars that would be prime targets in the search for extraterrestrial life. These features exemplify the considerable scope for study and understanding of astrobiology and planetary science that exists in the Flinders Ranges and surrounds.

\section{Acknowledgements}

We thank Phil Schmidt, Narelle Neumann, John Keeling and Natalie Kositcin for their helpful comments and reviews. Matilda Thomas and Jonathan Clarke publish with the permission of the Chief Executive Officer of Geoscience Australia.

\section{References}

Allwood, A., Walter, M., Burch, I. and Kamber, B., 2007, 3.43-Billion-yearold stromatolite reef from the Pilbara Craton of Western Australia: Ecosystem-scale insights to early life on Earth: Precambrian Research, v. 158, pp. $198-227$.

Allen, C.C., Westall, F. and Schelble, R.T., 2001, Importance of a martian hematite site for astrobiology: Astrobiology, v. 1, pp. 111-123.

Allen, C.C., Probst, L.W., Flood, B.E., Longazo, T.G., Schelble, R.T. and Westall, F., 2004, Meridiani Planum hematite deposit and the search for evidence of life on Mars - iron mineralization of microorganisms in rock varnish: Icarus, v. 171, pp. 20-30.

Anitori, R.P., Trott, C., Saul, D.J., Bergquist, P.L. and Walter, M.R., 2002, A culture-independent survey of the bacterial community in a radon hot spring: Astrobiology, v. 2, pp. 255-270.

Bishop, M.A., 1999, Comparative geomorphology of seasonally active crescentic dunes: Nili Patera, Mars and Strzelecki Desert, Earth: Fifth International Conference on Mars. Abstract 6069. LPI Contribution 972, Lunar and Planetary Institute, Houston.

Bock, G.R. and Goode, J.A. (eds.), 1996, Evolution of Hydrothermal Ecosystems on Earth (and Mars?): Ciba Foundation Symposium 202, John Wiley and Sons, Chichester, UK.

Bons, P.D. and Montenari, M., 2005, The formation of antitaxial calcite veins with well-developed fibres, Oppaminda Creek, South Australia: Journal of Structural Geology, v. 27, pp. 231-248.

Bons, P.D., Montenari, M., Bakker, R. J. and Erlburg, M.A., 2007, Potential evidence of fossilised Neoproterozoic deep life: SEM observations on calcite veins from Oppaminda Creek, Arkaroola, South Australia: International Journal of Earth Sciences, doi 10.1007/s00531-0070245-4.

Brasier, M.D., Green, O.R., Jephcoat, A.P., Kleppe, A.K., Van Kranendonk, M.J., Lindsay, J.F., Steele, A. and Grassineau, N.V., 2002, Questioning the evidence for Earth's oldest fossils: Nature, v. 416, pp. 76-81.

Brown, A.J. and Thomas, M.D., 2004, Hyperspectral infrared investigations of metamorphosed rocks at the Mars Analogue environment around the
Mt Painter Inlier, Arkaroola, South Australia: Proceedings of the 4th Australian Mars Exploration Conference, Adelaide, South Australia, JulyAugust 2004. Mars Society Australia.

Brown, A.J., West, M.D. and Thomas, M., 2004, Remote methods for detection of hydrothermal activity in Mars analogue regions, an example from the Mt. Painter Inlier, northern Flinders Ranges, South Australia: Proceedings of the 4th Australian Mars Exploration Conference, July-August 2004. Mars Society Australia.

Brugger, J., Long, N., McPhail, D. and Plimer, I. 2005, An active amagmatic hydrothermal system: The Paralana hot springs, Northern Flinders Ranges, South Australia: Chemical Geology, v. 222, pp. 35-64.

Brugger, J.I., Wulser, P.A. and Foden, J., 2011, Genesis and preservation of a uranium-rich Paleozoic epithermal system with a surface expression (northern Flinders Ranges, South Australia): Radiogenic heat driving regional hydrothermal circulation over geological timescales: Astrobiology, v. 11, pp. 499-508.

Carlton, A. 2002. A possible sample of the ancient deep hot biosphere from Mt Gee: BSc (Hons) thesis, Macquarie University, Sydney, Australia (unpublished).

Catling, D.C. and Moore, J.M., 2003, The nature of coarse-grained hematite and its implications for the early environment of Mars: Icarus, v. 165, pp. 277-300.

Coats, R.P., 1972, Explanatory notes for the Copley 1: 250,000 Geological Series Sheet SH/54-9: Department of Mines, South Australia.

Coats, R.P. and Blissett, A.H., 1971, Regional and economic geology of the Mount Painter province: Geological Survey of South Australia, Bulletin 43, 426 pp.

Collier, J.B., 2000, Geology and the associated mineralisation of the Arkaroola Creek area, South Australia: BSc (Hons) thesis, University of Melbourne (unpublished).

Compston, W., Williams, I.S., Jenkins, R.J.F., Gostin, V.A. and Haines, P.W., 1987, Zircon age evidence for the Late Precambrian Acraman ejecta blanket: Australian Journal of Earth Sciences, v. 34, pp. 435-445.

Cowan, E.A., Seramur, K.C., Cai, J. and Powell, R.D., 1999, Cyclic sedimentation produced by fluctuations in meltwater discharge, tides and marine productivity in an Alaskan fjord: Sedimentology, v. 46, pp. 1109-1126.

Davey, J.E. and Hill, S.M., 2007, Incorporating surficial geology and the sedimentary record into tectonic driven landscape evolution models: 5 th Sprigg Symposium, Geological Society of Australia, Abstracts, v. 87, pp. $11-14$

Drexel, J.F. and Major, R.B. 1987, Geology of the uraniferous breccia near Mt Painter, South Australia and revision of rock nomenclature: Geological Survey of South Australia Quarterly Notes 104, Geological Survey of South Australia, Adelaide.

Drexel, J.F. and Preiss, W.V. (eds.), 1995, The Geology of South Australia, volume 2, The Phanerozoic: Geological Survey of South Australia, Bulletin 54, 347 pp.

Eugster, H.P. and Jones, B.F., 1967, Gels composed of sodium-aluminium silicate, Lake Magadi, Kenya: Science, v. 161, pp. 160-163.

Foden, J., Elburg, M.A., Dougherty-Page, J. and Burtt, A., 2006, The timing and duration of the Delamerian Orogeny: Correlation with the Ross Orogen and implications for Gondwana assembly: Journal of Geology, v. 114 , pp. 189-210.

Foster, D.A., Murphy, J.M. and Gleadow, A.J.W., 1994, Middle Tertiary hydrothermal activity and uplift of the northern Flinders Ranges, South Australia: insights from apatite fission-track thermochronology: Australian Journal of Earth Sciences, v. 41, pp. 11-17.

Fournier, R.O., Thompson, J.M., Cunningham, C.G. and Hutchinson, R.A., 1991, Conditions leading to recent small hydrothermal explosion at Yellowstone National Park: Geological Society of America, Bulletin, v. 103, pp. 1114-1120

Fyfe, W.S. 1996, The biosphere is going deep: Science, v. 273, p. 448.

Giddings, J.A., Wallace, M.W. and Woon, E.M.S., 2009, Interglacial carbonates of the Cryogenian Umberatana Group, northern Flinders Ranges, South Australia: Australian Journal of Earth Sciences, v. 56, pp. 907-925.

Gostin, V.A., Haines, P.W., Jenkins, R.J.F., Compston, W. and Williams, I.S., 1986, Impact ejecta horizon within late Precambrian shales, Adelaide Geosyncline, South Australia: Science, v. 233, pp. 198-200.

Gostin, V.A., Keays, R.R. and Wallace, M.W., 1989, Iridium anomaly from the Acraman impact ejecta horizon: impacts can produce sedimentary 
iridium peaks: Nature, v. 340, pp. 542-544.

Gostin, V.A., McKirdy, D.M., Webster, L.J. and Williams, G.E., 2010, Ediacaran ice-rafting and coeval asteroid impact, South Australia: insights into the terminal Proterozoic environment: Australian Journal of Earth Sciences, v. 57, pp. 859-869.

Grey, K., Walter, M.R. and Calver, C.R., 2003, Neoproterozoic biotic diversification: Snowball Earth or aftermath of the Acraman impact? Geology, v. 31, pp. 459-462.

Hill, S.M., 2008, A regolith and landscape evolution framework for mineral exploration under cover in the northern Flinders Ranges-Frome Embayment, South Australia: Geological Society of Australia, Abstracts, v. 89 , p. 135.

Hill, S.M. and Hore, S.B., 2009, Northern Flinders Ranges-Lake Frome Plains uranium exploration under cover: new geological insights through collaboration: MESA Journal, v. 53, pp. 28-31.

Hoffman, P.F. and Schrag, D.P., 2002, The snowball Earth hypothesis: testing the limits of global change: Terra Nova, v. 14, pp. 129-155.

Hofmann, B.A. and Farmer, J. D., 2000, Filamentous fabrics in low temperature mineral assemblages: are they fossil biomarkers? Implications for the search for a subsurface fossil record on the early Earth and Mars: Planetary and Space Science, v. 48, pp. 1077-1086.

Hore, S.J., 2008, Mount Painter region: uranium mineralising systems and a new regional exploration approach: South Australian Resources and Energy Investment Conference 2008, Adelaide (conference presentation).

Hore, S.J. and Hill, S.M., 2009, Field guide to the Proterozoic Mt Painter Inlier and Mesozoic to Cenozoic basins of the Lake Frome region, in Skirrow, R.G. (ed), Uranium ore-forming systems of the Lake Frome region, South Australia: Geoscience Australia Record 2009/40.

Hore, S.J., Fidler, R., McInnes, R. and Ragless, J., 2005, Mount Painter Geochemistry - an old terrain revisited with new science: MESA Journal, v. 38, pp. 8-14.

Knoll, A.H., Walter, M.R., Narbonne, G.M. and Christie-Blick, N., 2006, The Ediacaran Period: a new addition to the geologic time scale: Lethaia, v. 39, pp. 13-30.

Laing, J.H., Clarke, J., Deckert, J., Gostin, V., Hoogland, J., Lemke, L., Leyden, J., Mann, G., Murphy, G., Stoker, C., Thomas, M., Waldie, J., Walter, M. and West, M.D., 2004, Using an Australian Mars analogue research facility for astrobiology education and outreach, in Norris, R.P. and Stootman, F.H. (eds.), Bioastronomy 2002: Life Among the Stars: International Astronomical Union, No. 213 Astronomical Society of the Pacific, San Francisco, CA, pp. 553-558.

Lambert, I.B., Drexel, J.F., Donnelly, T.H. and Knutson, J., 1982, Origin of breccias in the Mount Painter area, South Australia: Journal of the Geological Society of Australia, v. 29, pp. 115-125.

Lemon, N.M. and Gostin, V.A., 1990, Glacigenic sediments of the late Proterozoic Elatina Formation and equivalents, Adelaide Geosyncline, South Australia, in Jago, J.B. and Moore, P.S. (eds), The Evolution of a Late Precambrian-Early Palaeozoic Rift Complex: The Adelaide Geosyncline: Geological Society of Australia, Special Publication, 16, pp. 149-163.

Marshall, C.P., 2007, Organic geochemistry of Archaean carbonaceous cherts from the Pilbara Craton, Western Australia, in Van Kranendonk, M.J., Smithies, H. and Bennett, V.C. (eds), Developments in Precambrian Geology, 15, pp. 897-921.

McKay, C.P. and Stoker, C.R., 1989, The early environment and its evolution on Mars: implications for Mars: Reviews of Geophysics, v. 27, pp. 189214.

McKirdy, D.M., Webster, L.J., Arouri, K.R., Grey, K. and Gostin, V.A., 2006, Contrasting sterane signatures in Neoproterozoic marine rocks of Australia before and after the Acraman asteroid impact: Organic Geochemistry, v. 37, pp. 189-207.

NASA Astrobiology Institute, 2008, About Astrobiology: NASA, 21 January 2008. http://astrobiology.nasa.gov/about-astrobiology/.

Ping, S.L., 1989, Cyclic morphologic changes of the ebb-tidal delta, Texel Inlet, The Netherlands: Geologie en Mijnbouw, v. 68, pp. 35-48.

Pinti, D.L., Hashizume, K. and Matsuda, J.I., 2001, Nitrogen and argon signatures in 3.8 to 2.8 Ga metasediments: Clues on the chemical state of the Archean ocean and the deep biosphere: Geochimica et Cosmochimica Acta, v. 65, pp. 2301-2315.

Preiss, W.V. (compiler), 1987, The Adelaide Geosyncline. Late Proterozoic stratigraphy, sedimentation, palaeontology and tectonics: Geological Survey of South Australia, Bulletin 53, 438 pp.
Preiss, W.V., 1993, Neoproterozoic, in Drexel, J.F., Preiss, W.V. and Parker, A.J. (eds), The Geology of South Australia, volume 1, The Precambrian: Geological Survey of South Australia, Bulletin 54, pp. 171-203.

Preiss, W.V., 2000, The Adelaide Geosyncline of South Australia and its significance in Neoproterozoic continental reconstruction: Precambrian Research, v. 100, pp. 21-63.

Preiss, W.V., Dyson, I.A., Reid, P.W., and Cowley, W.M., 1998, Revision of lithostratigraphic classification of the Umberatana Group: MESA Journal, v. 9, pp. 36-42.

Preiss, W.V., Gostin, V.A., McKirdy, D.M., Ashley, P.M., Williams, G.E. and Schmidt, P.W., 2011, The glacial succession of Sturtian age in South Australia - the Yudnamutana Subgroup, in The Geological Record of Neoproterozoic glaciations, Geological Society of London, Memoir 36, pp. 701-712.

Saunders, J.A., 1994, Silica and gold textures in Bonanza ores of the sleeper deposit, Humbolt County, Nevada: evidence for colloids and implications for epithermal ore-forming processes: Economic Geology, v. 89, pp. 628638.

Schmidt, P.W. and Williams, G.E., 1995, The Neoproterozoic climatic paradox: equatorial palaeolatitude for Marinoan glaciation near sea level in South Australia: Earth and Planetary Science Letters, v. 134, pp. 107-124.

Schmidt, P.W. and Williams, G.E., 1996, Palaeomagnetism of the ejectabearing Bunyeroo Formation, late Neoproterozoic, Adelaide fold belt, and the age of the Acraman impact: Earth and Planetary Science Letters, v. 144 , pp. $347-357$.

Schmidt, P.W., Williams, G.E. and Embleton, B.J.J., 1991, Low palaeolatitude of Late Proterozoic glaciation: early timing of remanence in haematite of the Elatina Formation, South Australia: Earth and Planetary Science Letters, v. 105, pp. 355-367.

Schmidt, P.W., Williams, G.E. and McWilliams, M.O., 2009, Palaeomagnetism and magnetic anisotropy of late Neoproterozoic strata, South Australia: Implications for the palaeolatitude of late Cryogenian glaciation, cap carbonate and the Ediacaran System: Precambrian Research, v. 174, pp. 34-52.

Schopf, J.W., 2006, Fossil evidence of Archean life: Philosophical Transactions of the Royal Society, Section B, v. 361, pp. 869-885.

Smith, A.B., 1992, Geology of the Yudnamutana Gorge-Paralana Hot Springs area and genesis of mineralisation at the Hodgkinson Prospect, Mt Painter Province, South Australia: BSc (Hons) thesis, University of Adelaide (unpublished).

Smith, N.D., Phillips, A.C. and Powell, R.D., 1990, Tidal drawdown: a mechanism for producing cyclic sediment laminations in glaciomarine deltas: Geology, v. 18, pp. 10-13.

Sohl, L.E., Christie-Blick, N. and Kent, D.V., 1999, Palaeomagnetic polarity reversals in Marinoan (ca. $600 \mathrm{Ma}$ ) glacial deposits of Australia: implications for the duration of low-latitude glaciation in Neoproterozoic time: Geological Society of America, Bulletin v. 111, pp. 1120-1139.

Sprigg R.C., 1945, Some aspects of the geomorphological of portion on the Mount Lofty Ranges: Transactions of the Royal Society of South Australia, v. 69 , pp. 277-304.

Thomas, M. and Walter, M.R., 2002, Application of hyperspectral infrared analysis of hydrothermal alteration on Earth and Mars: Astrobiology, v. 2, pp. 335-351.

Thomas, M. and Walter, M.R., 2004, Infrared hyperspectral analysis of hydrothermal alteration on Earth and Mars? Abstracts, $17^{\text {th }}$ Australian Geological Convention, Hobart, Tasmania.

Twidale, C.R. and Bourne, J.A., 1996, The development of the land surface, in Tyler, M.J., Twidale, C.R., Davies, M. and Wells, C.B. (eds), Natural history of the north east deserts: Royal Society of South Australia, pp. $46-62$

Twidale, C.R. and Wopfner, H., 1996, Dune fields, in Tyler, M.J., Twidale, C.R., Davies, M. and Wells, C.B. (eds), Natural history of the north east deserts: Royal Society of South Australia, pp. 45-60.

Van Kranendonk, M.F. 2006, Volcanic degassing, hydrothermal circulation and the flourishing of early life on Earth: A review of the evidence from c. 3490-3240 Ma rocks of the Pilbara Supergroup, Pilbara Craton, Western Australia: Earth Science Reviews, v. 74, pp. 197-240.

Waclawik, V. and Gostin, V., 2006, Significance of remnant gravel lags as landscape evolution indicators, Arkaroola Mars analogue region geology, in Clarke, J.D.A. (ed), Mars Analog Research: Science and Technology Series, v. 111. American Astronautical Society, San Diego, California, pp. 107-114. 
Waldie, J.M.A. and Cutler, N.A., 2006, The flexibility of mechanical counter pressure space suit gloves, in Clarke, J.D.A. (ed), Mars Analog Research: Science and Technology Series, v. 111. American Astronautical Society, San Diego, California, pp. 161-174.

Wallace, M.W., Gostin, V.A. and Keays, R.R., 1996, Sedimentology of the Neoproterozoic Acraman impact-ejecta horizon, South Australia: AGSO Journal of Australian Geology and Geophysics, v. 16, pp. 443-451.

Walter, M.R. and Des Marais, D.J., 1993, Preservation of biological information in thermal spring deposits: developing a strategy for the search for fossil life on Mars: Icarus, v. 101, pp. 129-143.

West, M.D., Clarke, J.D.A., Laing, J.H., Willson, D., Waldie, J., Murphy, G.M. and Mann, G.A., 2009, Testing technologies and strategies for exploration in Australian Mars analogues: Planetary and Space Science, v. 58 , pp. $658-670$.

Williams, G.E., 1986, The Acraman impact structure: source of ejecta in late Precambrian shales, South Australia: Science, v. 233, pp. 200-203.

Williams, G.E., 1991, Upper Proterozoic tidal rhythmites, South Australia: sedimentary features, deposition, and implications for the earth's palaeorotation, in Smith, D.G., Reinson, G.E., Zaitlin, B.A. and Rahmani, R.A. (eds), Clastic Tidal Sedimentology: Canadian Society of Petroleum Geologists Memoir, 16, pp. 161-177.

Williams, G.E., 1996, Soft-sediment deformation structures from the Marinoan glacial succession, Adelaide foldbelt: implications for the palaeolatitude of late Neoproterozoic glaciation: Sedimentary Geology, v. 106, pp. 165175.

Williams, G.E., 2000, Geological constraints on the Precambrian history of

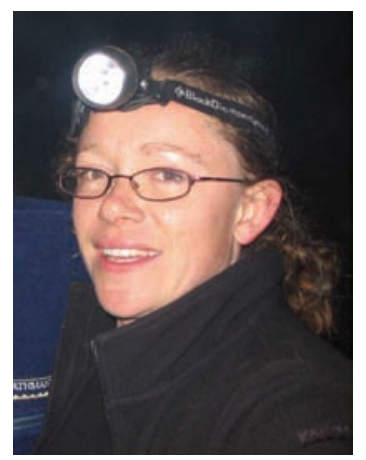

Matilda Thomas is a geologist at Geoscience Australia and has worked in regolith mapping, mineral exploration and applied spectroscopy since 2002. She also worked as a researcher for the space science exhibition "To Mars and Beyond" at the National Museum of Australia. Her interests include hyperspectral technologies and planetary science, as well as speleology and extremophile ecology.

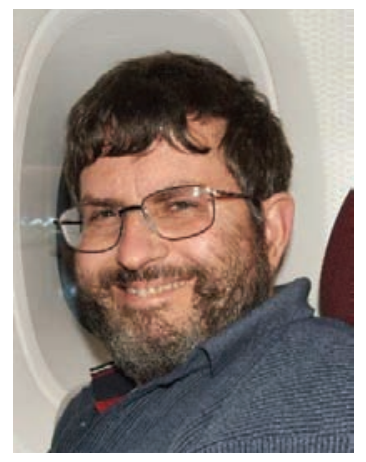

Jon Clarke is a geologist with 25 years' experience, mostly in the minerals and energy industries and has also worked in the university and government sectors. He currently works in the fields of aquifer mapping and characterisation across Australia for Geoscience Australia and is vice president of Mars Society Australia. Jon's Mars interests include terrestrial analogues of martian features including springs, slopes, and inverted channels, habitat design.

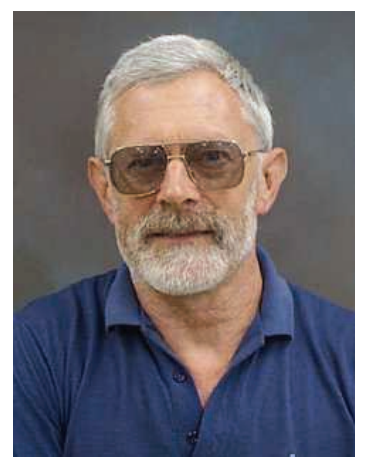

George Williams received an MSc in geology from the University of Melbourne in 1963 and a PhD in sedimentology from the University of Reading in 1966. His subsequent work has been divided between industry and research based at the University of Adelaide, much in association with the CSIRO. He was awarded a DSc by the University of Reading in 1998.
Earth's rotation and the Moon's orbit: Reviews of Geophysics, v. 38, pp. 37-59.

Williams, G.E., 2004, Earth's Precambrian rotation and the evolving lunar orbit: implications of tidal rhythmite data for palaeogeophysics, in Eriksson, P.G., Altermann, W., Nelson, D.R., Mueller, W.U. and Catuneanu, O. (eds), The Precambrian Earth: Tempos and Events: Developments in Precambrian Geology, v. 12, pp. 473-482. Elsevier, Amsterdam.

Williams, G.E. and Gostin, V.A., 2005, Acraman-Bunyeroo impact event (Ediacaran), South Australia, and environmental consequences: twentyfive years on: Australian Journal of Earth Sciences, v. 52, p. 607-620.

Williams, G.E. and Wallace, M.W., 2003, The Acraman asteroid impact, South Australia: magnitude and implications for the late Vendian environment: Journal of the Geological Society of London, v. 160, pp. 545554.

Williams, G.E., Gostin, V.A., McKirdy, D.M. and Preiss, W.V., 2008, The Elatina glaciation, late Cryogenian (Marinoan Epoch), South Australia: Sedimentary facies and palaeoenvironments: Precambrian Research, v. 163 , pp. $307-331$.

Williams, G.E., Gostin, V.A., McKirdy, D.M., Preiss, W.V. and Schmidt, P.W., 2011, The Elatina glaciation (late Cryogenian), South Australia, in The Geological Record of Neoproterozoic glaciations, Geological Society of London, Memoir 36, pp. 713-721.

Young, G.M. and Gostin, V.A., 1989, An exceptionally thick upper Proterozoic (Sturtian) glacial succession in the Mount Painter Area, South Australia: Geological Society of America, Bulletin, v. 101, pp. 834-845.

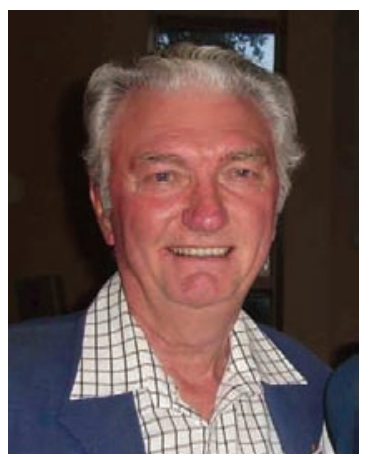

Victor Gostin is a retired Associate Professor in Geology and Geophysics at the University of Adelaide. His scientific interests include the origins and evolution of the solar system and of life, meteorite impacts, earth history, environmental geoscience, and the effects of natural phenomena on the course of human history. His other interests include sketching the Australian outback.

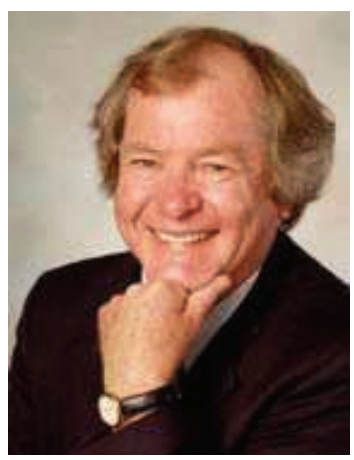

Malcolm Walter is a Professor of Astrobiology at the University of New South Wales in Sydney. He is Director of the Australian Centre for Astrobiology based at that university. He has worked for 35 years on the geological evidence of early life on Earth, including the earliest convincing evidence of life. He is a member of the Executive Council of NASA's Astrobiology Institute. He also works as an oil exploration consultant. 